УДК 577.23:612.015.

O. V. Lozinsky, PhD student

Department of Biochemistry and Biotechnology,

Precarpathian National University named after Vassyl Stefanyk,

57, Shevchenko Str., Ivano-Frankivsk, 76025, Ukraine,

e-mail: lozinsky_o@ukr.net

\title{
THE INFLUENCE OF SODIUM NITROPRUSSIDE, POTASSIUM FERROCYANIDE AND 2,4-DINITROPHENOL ON THE METABOLISM AND URIC ACID CONTENT IN DROSOPHILA MELANOGASTER
}

\begin{abstract}
The toxicity of potassium ferrocyanide (PFC) and sodium nitroprusside (SNP) and protective effects of 2.4-dinitrophenol (DNP) under PFC or SNP treatment were tested on the Drosophila melanogaster model system. Fly larvae were bred on food supplemented with PFC or SNP at concentrations of $1.0 \mathrm{mM}$ and mixtures with DNP in concentrations of 0.50 and $1.25 \mathrm{mM}$, either alone or in combination with 1.0 mM PFC or SNP. Larval treatment with PFC or SNP resulted in higher uric acid and lower triglycerides content in adult flies, while DNP in mixtures with PFC or SNP relieved these effects. Furthermore, SNP treatment resulted in lower ALT and AST activities either alone or in mixtures with DNP. The potential mechanisms of protective DNP effects against PFC or SNP toxicity are discussed.
\end{abstract}

Key words: Drosophila melanogaster, oxidative stress, potassium ferrocyanide, sodium nitropruside, 2.4-dinitrophenol.

Potassium ferrocyanide $\left[\mathrm{K}_{4} \mathrm{Fe}(\mathrm{CN})_{6}\right]$ is a hexacyanoferrate compound as well as potassium ferricyanide $\left[\mathrm{K}_{3} \mathrm{Fe}(\mathrm{CN})_{6}\right]$ and ferric hexacyanoferrate $\left(\mathrm{Fe}_{4}\left[\mathrm{Fe}(\mathrm{CN})_{6}\right]_{3}\right)$. Despite the presence of cyanide ions, hexacyanoferrate compounds are generally considered to be nontoxic because of the tight binding between the cyanide ions and the metal ions that prevents the release of free cyanide $[9,17]$. While studies on humans and animals exposed to iron-complexed cyanide are limited, the available works indicate very low PFC toxicity, even at relatively high exposure levels [3, 9]. However, C. Payen and colleagues (2010) reported the first case ever published on death after acute poisoning with PFC [9]. Sodium nitroprusside is a water-soluble iron nitrosyl complex. In previous studies on yeast [12] and flies [19], have been founded that SNP induced mild oxidative/ nitrosative stress in both organisms. Also have been registered that the toxicity of SNP might arise not just from its direct effects, but also from its decomposition products such as nitric oxide and iron ions [19]. 2.4-dinitrophenol has been long known to be toxic at high concentrations due to effects related to uncoupling of mitochondrial oxidative phosphorylation, whereas at low concentrations it protects neurons against $\beta$-amyloid toxicity [4], neudegeneration [11, 13], and different types of insult [20]. Other similar studies demonstrated that DNP at nontoxic concentrations stimulated neurite outgrowth, neuronal differentiation and even extended murine lifespan [14] as well as lifespan in yeasts [6] and flies [16]. Taking into account the above mentioned data, were interested 
to investigate the influence of PFC, SNP and DNP separately and in combination on the protein and fat metabolism as well as on the uric acid content in Drosophila.

The present study examined the possible protective effect of DNP against PFC and SNP-induced toxicity in vivo on D. melanogaster with the objective of understanding the effects of PFC, SNP and DNP on the on the protein and fat metabolism as well as on the uric acid content in Drosophila.

\section{Material and methods}

The D. melanogaster strain $w^{1118}$ was obtained from stock-centers or collaborators. Stock flies and larvae were reared on yeast-corn-molasses (regular) food with constant illumination at $25 \pm 1{ }^{\circ} \mathrm{C}$. Nipagin $0.2 \%$ (methyl- $p$-hydroxybenzoate) was added to the medium to inhibit mold growth. For all time course experiments, control larvae were fed with food containing $10 \%$ sucrose, $10 \%$ yeast and $1 \%$ of agar-agar (SY diet); and experimental groups were fed the same food, but supplemented with SNP (1.0 mM), PFC (1.0 mM), DNP (0.5 or $1.25 \mathrm{mM}$ ) or one of mixtures (SNP $1.0 \mathrm{mM}+$ DNP $0.5 \mathrm{mM}$, SNP $1.0 \mathrm{mM}$ + DNP $1.25 \mathrm{mM}$, PFC $1.0 \mathrm{mM}$ + DNP $0.5 \mathrm{mM}$ or PFC $1.0 \mathrm{mM}+$ DNP $1.25 \mathrm{mM})$.

Two-day-old flies were separated by sex and only females were used for analysis. Flies were homogenized using a Potter-Elvejhem glass homogenizer $(1: 10 \mathrm{w}: \mathrm{v})$ in cold $50 \mathrm{mM}$ potassium phosphate (KPi) buffer, $\mathrm{pH} 7.5$, containing $0.5 \mathrm{mM}$ EDTA and $1 \mathrm{mM}$ PMSF. After centrifugation at $16000 \times \mathrm{g}$ for 15 minutes at $4{ }^{\circ} \mathrm{C}$ in an Eppendorf $5415 \mathrm{R}$ centrifuge (Germany), the supernatants containing water soluble proteins were collected and used for different assays and protein measurements using Specoll 211 (Carl Zeiss Jena, Germany) and Microlab 300 (Vital Scientific, Netherlands) spectrophotometer. For uric acid assays supernatants were additionally treated for $15 \mathrm{~min}$ at $70{ }^{\circ} \mathrm{C}$ in order to inactivate all endogenous enzymes, including uricase. The concentration of uric acid was determined using an enzymatic colorimetric standard kit with uricase and peroxidase (Cormay, Poland), according to manufacturer's instructions. The uric acid concentration was expressed as micromoles per gram of fly wet weight. Soluble triglyceride was measured using a commercially available kit (Cormay, Poland) following the manufacturer's suggested protocol. The triglycerides concentration was expressed as micromoles per gram of fly wet weight. The activities of ALT and AST were determined using an enzymatic colorimetric standard kit (Cormay, Poland), according to manufacturer's instructions. Briefly, activity of ALT was measured by optimized, modified kinetic method with NADH and Tris buffer, without pyridoxal phosphate. The final concentrations of reagents were: Tris (pH 7.5) - $100 \mathrm{mmol} / \mathrm{l}, \mathrm{L}-$ alanine $-500 \mathrm{mmol} / \mathrm{l}, \mathrm{LDH}>36,7$ $\mu \mathrm{kat} / \mathrm{l}, 2-$ oxoglutarate $-15 \mathrm{mmol} / \mathrm{l}$, NADH $-0.18 \mathrm{mmol} / \mathrm{l}$. The activity of AST was measured by kinetic method with NADH and Tris buffer, without pyridoxal phosphate. The final concentrations of reagents were: Tris $(\mathrm{pH} 7.8)-80 \mathrm{mmol} / \mathrm{l}, \mathrm{L}-$ aspartate -240 $\mathrm{mmol} / \mathrm{l}, \mathrm{MDH}>10 \mu \mathrm{kat} / \mathrm{l}, \mathrm{LDH}>20 \mu \mathrm{kat} / \mathrm{l}, 2$-oxoglutarate $-15 \mathrm{mmol} / \mathrm{l}, \mathrm{NADH}-0.18$ 
$\mathrm{mmol} / \mathrm{l}$. The rate of absorbance changing at $\mathrm{l}=340 \mathrm{~nm}$ was directly proportional to alanine or aspartate aminotransferases activities. One unit of enzyme activity is defined as the amount of the enzyme that consumed $1 \mu \mathrm{mol}$ of substrate or generated $1 \mu \mathrm{mol}$ of product per minute. Activities of the enzymes were expressed as international units (or milliunits) per milligram of soluble protein. Protein concentration was determined by the Coomassie brilliant blue G-250 dye-binding method [2] with bovine serum albumin as the standard. Experimental data are expressed as means \pm SEM. Statistical analysis was performed using a two-tailed Student's t-test.

\section{Results}

It is a well-documented fact that Drosophila females are more resistant to stress conditions such as starvation, high temperature, and dietary xenobiotics than are males [10]. Current study, not aim to evaluate differences and sex-dependent sensitivity to treatment, but to investigate the possible protective effects of DNP against SNP and PFC-induced toxicity. For convenience, throughout the text, have been used the abbreviations C, D0.5, D1.25, S1, S1D0.5, S1D1.25, FC1, FC1D0.5 and FC1D1.25 to denote the control and treatment groups that received food supplemented with DNP $0.5 \mathrm{mM}$, DNP 1.25 mM, SNP $1.0 \mathrm{mM}$, SNP $1.0 \mathrm{mM}$ + DNP $0.5 \mathrm{mM}$, SNP $1.0 \mathrm{mM}+$ DNP $1.25 \mathrm{mM}$, PFC $1.0 \mathrm{mM}$, PFC $1.0 \mathrm{mM}$ + DNP $0.5 \mathrm{mM}$, PFC $1.0 \mathrm{mM}$ + DNP $1.25 \mathrm{mM}$, respectively.

The activity of ALT in control group was near $2000 \mathrm{U} / \mathrm{mg}$ protein and was unaffected in all experimental groups, except S1D1.25 group where activity was $27 \%$ significantly lower in comparison to control ones as well as vs S1 group (Fig. 1A). The activity of AST in control group was near $4000 \mathrm{U} / \mathrm{mg}$ protein. In the S1 group as well as in the SNP+DNP groups investigated parameter was significantly lower (Fig. 1B).

The levels of whole body soluble TAG was highest in the control group $(\sim 1200 \mu \mathrm{mol} /$ gww) and drastically decreased in D0.5 and D1.25 experimental groups (by 38 and $46 \%$, respectively), as well as in $\mathrm{FC} 1$ and $\mathrm{S} 1$ groups, however DNP partially relives these effects. For instance, in the FC1D1.25 and S1D1.25 groups TAG levels were significantly higher versus FC1 and S1 group, respectively (Fig. 2A). Figure 2B shows that the uric acid concentration in the S1 group was higher by up to 4-folds as compared with controls; however, in D0.5 and D1.25 groups the uric acid levels were significantly lower than in controls.

Furthermore, DNP relieved effects of SNP in the S1D0.5 and S1D1.25 groups. For instance, in the latter group, uric acid concentration was reduced to near control values and was significantly lower than in the $\mathrm{S} 1$ group.

Furthermore, DNP relieved effects of PFC in the FC1D0.5 and FC1D1.25 groups. For instance, in the latter group, uric acid concentration was reduced to control values and was significantly lower than in the $\mathrm{FC} 1$ group. 


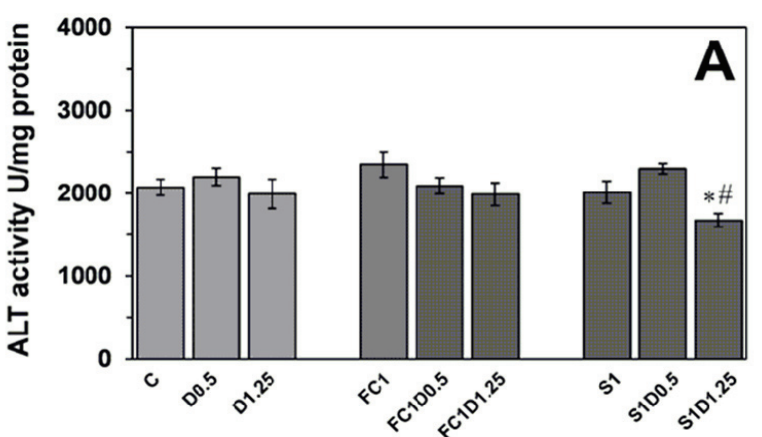

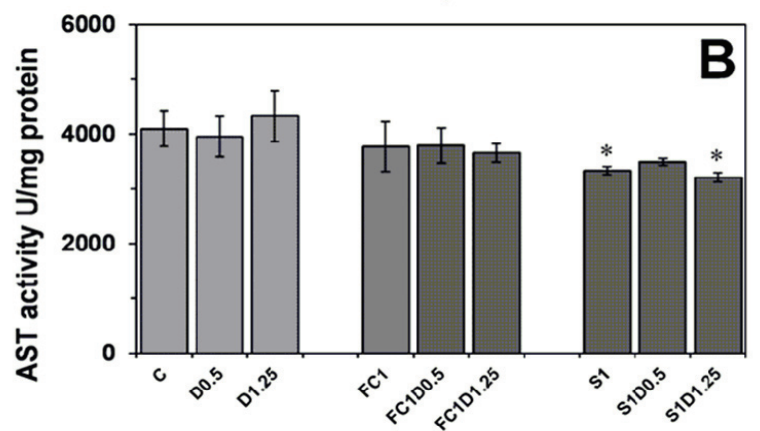

Control and treatment groups (details see in text)
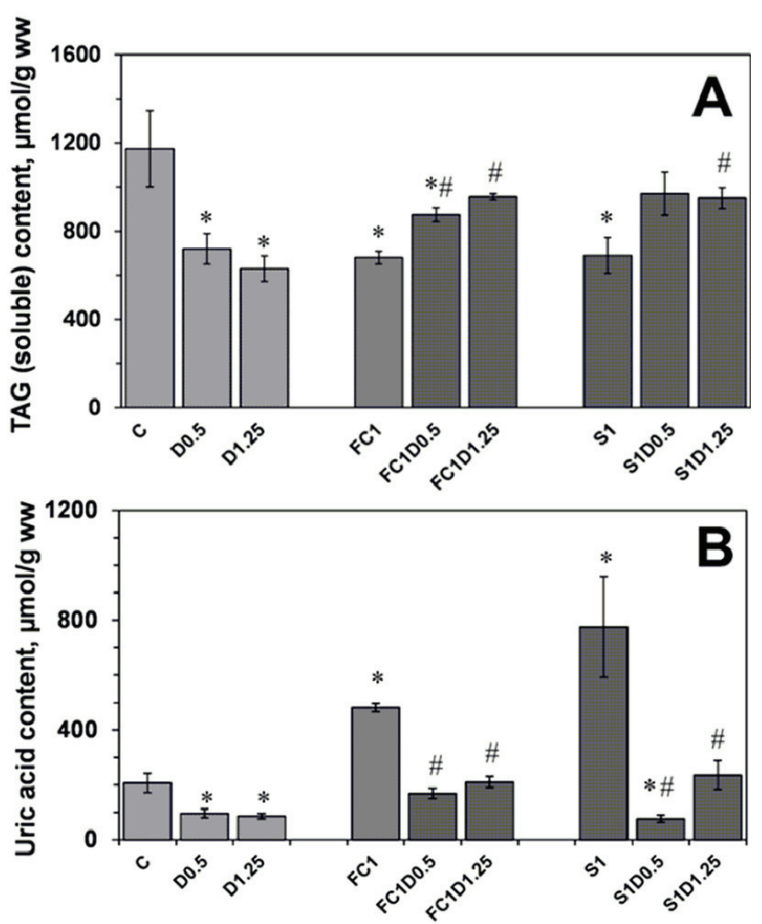

Control and treatment groups (details see in text)
Figure 1 . The activity of alanine aminotransferase (A) and aspartate aminotransferase (B) in 2-day-old female flies $\left(w^{1118}\right)$ emerged from Drosophila larvae grown in SNP, PFC, DNP or SNP+DNP, PFC+DNP-treated medium during development. Data are means \pm S.E.M, $\mathrm{n}=5-6 . *$ Significantly different from the control group, $\mathrm{P}<0.05$. \#Significantly different from the $\mathrm{S} 1$ or $\mathrm{FC} 1$ group, $\mathrm{P}<0.05$.

Figure $2 \mathrm{~B}$ also shows that the uric acid concentration in the $\mathrm{FC} 1$ group was higher by $133 \%$ as compared with control; however, in D0.5 and D1.25 groups the uric acid levels were significantly lower than in controls (by $\sim 50 \%$ ).

Figure 2. The content of whole body triacylglycerols (A) and uric acid (B) in 2-day-old female flies $\left(w^{1118}\right)$ emerged from Drosophila larvae grown in SNP, $\mathrm{PFC}, \mathrm{DNP}$ or SNP+DNP, PFC+DNPtreated medium during development. Data are means \pm S.E.M, $n=5-6$. Other information as in Figure 1. 


\section{Discussion}

In previous study have been showed that SNP and PFC caused a developmental delay and decreased total viability of fruit flies [19]. We suggested that this was closely connected with oxidative/nitrosative stress induced by SNP or PFC or by products of SNP/ $\mathrm{PFC}$ decomposition such as iron ions, nitrites and cyanides. In present study we were interested to investigate the influence of PFC, SNP and DNP separately and in combination on the protein (ALT, AST activities) and fat metabolism (TAG content) as well as on the uric acid content (oxidative stress marker) in Drosophila. The activity of ALT was unaffected in all experimental groups, except S1D1.25 group where activity was significantly lower in comparison to control ones as well as vs S1 group. The activity of AST in the $\mathrm{S} 1$ group as well as in the SNP+DNP groups was significantly lower, indicating that SNP either alone or in mixture affecting protein metabolism in D. melanogaster, particularly activities of ALT and AST. Next have been investigated fat metabolism in D. melanogaster in form of whole body soluble TAG content and was obtained interesting results. The levels of whole body soluble TAG was highest in the control group and drastically decreas ed in D0.5 and D1.25 groups, as well as in FC1 and S1 groups, however, in the FC1D1.25 and S1D1.25 groups TAG levels were significantly higher versus FC1 and S1 group, respectively, indicating that DNP partially restores TAG levels under SNP or PFC treatment.

Uric acid is an important scavenger of free radicals in biological systems, including insects [5, 21]. Hilliker and colleagues (1992) found that urate is crucial in antioxidative defence in vivo in D. melanogaster [21]. Uric acid can act either by directly scavenging ROS/RNS or by binding transition metals [7, 21]. Have been shown, that SNP and PFC treatment drastically increased urate levels. One may suggest that urate levels in this case increased in response to elevated ROS levels, which is supported from our assessments of other oxidative stress markers. Furthermore, the presence of DNP reduced uric acid levels to near control ranges indicating reduced ROS levels in SNP/DNP and PFC/DNP groups.

In mitochondria, minor changes in respiratory rates are typically accompanied by very considerable decreases in ROS release [8, 18]. Uncoupling diminishes mitochondrial ROS release through a variety of mechanisms $[15,18]$. First, higher respiratory rates increase oxygen consumption, resulting in lower oxygen tensions in the mitochondria. This decreases generation of $\mathrm{O}_{2}^{--}$, the main ROS produced by mitochondria [1]. The second effect of enhanced respiratory rates on ROS release is the maintenance of electron transport chain components in more oxidized states in which they cannot donate electrons to oxygen, resulting in $\mathrm{O}_{2}^{-}$- formation. These mechanisms are relevant to presented data, since was showed that DNP (due to its uncoupling effects) appears to protect Drosophila from the negative impacts of SNP or PFC by counteracting the effects of SNP or PFC on the content of triglycerides and uric acid levels. 


\section{Conclusions}

1. SNP treatment resulted in lower ALT and AST activities either alone or in mixtures with DNP.

2. Larval treatment with PFC or SNP resulted in higher uric acid and lower triglycerides content in adult flies, while DNP in mixtures with PFC or SNP relieved these effects.

\section{References}

1. Balaban R.S. Mitochondria, oxidants, and aging / R.S. Balaban, S. Nemoto and T. Finkel // Cell. - 2005. Vol. 120, N. 4. - P. 483-495.

2. Bradford M. M. A rapid and sensitive method for the quantitation of microgram quantities of protein utilizing the principle of protein-dye binding / M. M. Bradford // Analytical Biochemistry. - 1976. Vol. 72, N. 1-2. - P. 248-254.

3. Chemistry, toxicology, and human health risk of cyanide compounds in soils at former manufactured gas plant sites / N. S. Shifrin, B. D. Beck, T. D. Gauthier, S. D. Chapnick [et al.] // Regular Toxicology and Pharmacology - 1996. - Vol. 23, N. 2. - P. 106-116.

4. DeFelice F. G. Novel neuroprotective, neuritogenic and anti-amyloidogenic properties of 2,4-dinitrophenol: The gentle face of Janus / F. G. De Felice, S. T. Ferreira// IUBMB Life. -2006. - Vol. 58, N. 4. - P. 185-191.

5. Felton G. W. Antioxidant systems in insects / G. W. Felton, C. B. Summers // Archives of Insect Biochemistry and Physiology. - 1995. - Vol. 29, N. 2. - P. 187-197.

6. Higher respiratory activity decreases mitochondrial reactive oxygen release and increases life span in Saccharomyces cerevisiae / M. H. Barros, B. Bandy, E. B. Tahara and A. J. Kowaltowski // Journal of Biological Chemistry. - 2004. - Vol. 279, N. 48. - P. 49883-49888.

7. Kaur H. Action of biologically-relevant oxidizing species upon uric acid. Identification of uric acid oxidation products / H. Kaur, B. Halliwell // Chemico-Biological Interactions. - 1990. Vol. 73, N. 2. - P. 235-247.

8. Korshunov S. S. High protonic potential actuates a mechanism of production of reactive oxygen species in mitochondria / S. S. Korshunov, V. P. Skulachev and A. A. Starkov // FEBS Letters. 1997. - Vol. 416, N. 1. - P. 15-18.

9. Lethal acute poisoning with potassium ferrocyanide / C. Payen, C. Combe, C. Le Meur, Y. Gaillard [et al.] // American Journal of Emergency Medicine. - 2010. - Vol. 28, N. 5. - P. 642-645.

10. Lin Y. J. Extended life-span and stress resistance in the Drosophila mutant methuselah / Y. J. Lin, L. Seroude, S. Benzer // Science. - 1998. - Vol. 282, N. 5390. - P. 943-946.

11. Liu D. Preventing NAD + depletion protects neurons against excitotoxicity / D. Liu, M. Pitta, M. P. Mattson // Annals of the New York Academy of Sciences. - 2008. - Vol. 1147, N. 1. P. 275-282.

12. Lushchak $O$. Sodium nitroprusside induces mild oxidative stress in Saccharomyces cerevisiae / O. Lushchak, V. Lushchak // Redox Report. - 2008. - Vol. 13, N. 4. - P. 144-152.

13. Madeiro da Costa R. F. 2,4-Dinitrophenol Blocks Neurodegeneration and Preserves Sciatic Nerve Function after Trauma / R. F. Madeiro da Costa, A. M. Blanco Martinez, and S. T. Ferreira // Journal of Neurotrauma. - 2010. - Vol. 27, N. 5. - P. 829-841.

14. Mild mitochondrial uncoupling in mice affects energy metabolism, redox balance and longevity / Caldeira da Silva C. C., Cerqueira F. M., Barbosa L. F. [et al.] // Aging Cell. - 2008. - V. 7, 4. P. 552-560. 
15. Mitochondrial superoxide: production, biological effects, and activation of uncoupling proteins / M. D. Brand, C. Affourtit, T. C. Esteves, K. Green [et al.] // Free Radical Biology and Medicine. 2004. - Vol. 37, N. 6. - P. 755-767.

16. Padalko V. I. Uncoupler of oxidative phosphorylation prolongs the lifespan of Drosophila / V. I. Padalko // Biochemistry (Moscow). - 2005. - Vol. 70, N. 9. - P. 986-989.

17. Pearce J. Studies of any toxicological effects of Prussian blue compounds in mammals - a review / J. Pearce // Food and Chemical Toxicology. - 1994. - Vol. 32, N. 6. - P. 577-582.

18. Skulachev V. P. Uncoupling: new approaches to an old problem of bioenergetics / V. P. Skulachev // Biochimica et Biophysica Acta. - 1998. - Vol. 1363, N. 2. - P. 100-124.

19. Sodium nitroprusside toxicity in Drosophila melanogaster: delayed pupation, reduced adult emergence, and induced oxidative/nitrosative stress in eclosed flies / O. V. Lozinsky, O. V. Lushchak, J. M. Storey, K. B. Storey [et al.] // Archives of Insect Biochemistry and Physiology. - 2012. Vol. 80, N. 3. - P. 166-185.

20. The mitochondrial uncoupler 2,4-dinitrophenol attenuates tissue damage and improves mitochondrial homeostasis following transient focal cerebral ischemia / A. S. Korde, L. C. Pettigrew, S. D. Craddock, W. F. Maragos // Journal of Neurochemistry. - 2005. - Vol. 94, N. 6. - P. 1676-1684.

21. Urate-null rosy mutants of Drosophila melanogaster are hypersensitive to oxygen stress / Hilliker A. J, Duyf B., Evans D. and Phillips J. P // Proceedings of the National Academy of Sciences. - 1992. - Vol. 89, N. 10. - P. 4343-4347.

\title{
О. В. Лозінський
}

Кафедра біохімії та біотехнології,

Прикарпатський національний університет ім. Василя Стефаника, вул. Шевченка, 57, Івано-Франківськ, 76025, Україна;

e-mail: lozinsky_o@ukr.net

\section{ВПЛИВ НІТРОПРУСИДУ НАТРІЮ, ФЕРРОЦІАНІДУ КАЛІЮ І 2,4- ДИНІТРОФЕНОЛУ НА МЕТАБОЛІЗМ І РІВЕНЬ СЕЧОВОЇ КИСЛОТИ В DROSOPHILA MELANOGASTER}

\begin{abstract}
Резюме
Токсичність ферроціаніду калію (ФЦК) і нітропрусиду натрію (НПН) і потенційний захисний ефект 2,4-дінітрофенолу (ДНФ) були вивчені на плодовій мушці Drosophila melanogaster. Личинки споживали ФЦК чи НПН у концентрації 1,0 мМ та у сумішах 3 ДНФ в концентраціях 0,5 та 1,25 мМ, окремо або в комбінації з 1,0 мМ ФЦК чи НПН. Споживання ФЦК чи НПН призвело до збільшення рівня сечової кислоти та зниження рівня тригліцеридів у дорослих мух, в той час як ДНФ в сумішах з ФЦК чи НПН частково нівелював дані ефекти. Крім того, споживання самого НПН, чи у сумішах з ДНФ, призводило до зниження активності аланін-та аспартат амінотрансферази.
\end{abstract}

Ключові слова: Drosophila melanogaster; оксидативний стрес; ферроціанід калію; нітропрусид натрію; 2,4-динітрофенол. 


\section{А. В. Лозинский}

Кафедра биохимии и биотехнологии,

Прикарпатский национальный университет им. Васыля Стефаника,

ул. Шевченко, 57, Ивано-Франковск, 76025, Украина;

e-mail: lozinsky_o@ukr.net

\section{ВЛИЯНИЕ НИТРОПРУССИДА НАТРИЯ, ФЕРРОЦИАНИДА КАЛИЯ И 2,4-ДИНИТРОФЕНОЛА НА МЕТАБОЛИЗМ И УРОВЕНЬ МОЧЕВОЙ КИСЛОТЫ В DROSOPHILA MELANOGASTER}

\section{Резюме}

Токсичность ферроцианида калия (ФЦК) и нитропруссида натрия (НПН) и потенциальный защитный эффект 2,4-динитрофенола (ДНФ) были изучены на плодовой мушке Drosophila melanogaster. Личинки потребляли ФЦК или НПН в концентрации 1,0 мМ и в смесях с ДНФ в концентрациях 0,5 и 1,25 мМ, отдельно или в комбинации с 1,0 мМ ФЦК или НПН. Потребление ФЦК или НПН привело к увеличению уровня мочевой кислоты и снижение уровня триглицеридов у взрослых мух, в то время как ДНФ в смесях с ФЦК или НПН частично нивелировал данные эффекты. Кроме того, потребление самого НПН, или в смесях с ДНФ, приводило к снижению активности аланин-и аспартат аминотрансферазы.

Ключевые слова: Drosophila melanogaster; окислительный стресс; ферроцианид калия; нитропруссид натрия; 2,4-динитрофенол.

Стаття надійшла до редакції 16.09.2013 